Community: volume 6, nomor 1, April 2020

p-ISSN: 2477-5746 e-ISSN: 2502-0544

\title{
KAWASAN WISATA KULINER JALAN RODA (JAROD) SEBAGAI RUANG EKSPRESI WAKTU LUANG (LEISURE) MASYARAKAT KOTA MANADO
}

\author{
Awaluddin Hasrin ${ }^{1}$, Abdul Rasyid Umaternate ${ }^{2}$, Sangputri Sidik ${ }^{3}$ \\ Pendidikan Sosiologi Universitas Negeri Manado ${ }^{1,2,3}$ \\ E-mail: awaluddin@unima.ac.id ${ }^{1}$ rumaternate@gmail.com² ${ }^{2}$, putrisidik@unima.ac.id ${ }^{3}$
}

\begin{abstract}
This paper aims to understand the practice of using leisure time in the Jalan Roda (Jarod) area of the city of Manado. This research is focused on coffee shops located in the culinary area of jalan roda in the city of Manado. The determination of this area by considering several aspects, namely the representation of coffee shops located in the city centers and the jalan roda area (Jarod) is a gathering point for all people in the city of Manado. Researchers used a qualitative descriptive analysis aimed at describing in depth the phenomenon of the existence of a culinary jalan roda in the city of Manado as a means or space for leisure expression for the people of Manado. Based on this research, jalan roda area (Jarod) the Manado City is a place where people can relax. This area is a gathering point for people from various backgrounds, ranging from students, brokers, artists, cultural figures, journalists, business people, and even public officials. Different from the concept of coffee, or modern coffee shops in general. Coffee shops in jalan roda (Jarod) is somewhat simpler. Far from modern impression. If in general the concept of modern coffee or coffee maker puts forward an attractive and instagramable interior design for the visitors. Jalan roda region (Jarod) actually retains it's classic style. The table model is made lengthwise so that everyone who visits can sit at the table with other people who have not been known before.
\end{abstract}

Keywords: Jalan Roda Region, Coffee Shops, Leisure Time. 
Community: volume 6, nomor 1, April 2020

p-ISSN: 2477-5746 e-ISSN: 2502-0544

\section{PENDAhULUAN}

Budaya minum kopi dewasa ini telah menjadi trend dan lifestyle baru bagi masyarakat. Semua kalangan mulai dari orang tua, anak muda, laki-laki maupun perempuan. Jika sebelumnya, kebiasaan minum kopi di kedai kopi merupakan hal yang dianggap biasa saja, tapi belakangan aktivitas minum kopi yang kadang disertai perbincangan dengan teman, keluarga, rekan kerja. Bahkan bagi beberapa orang, menjadikan warung kopi sebagai tempat menjalankan aktivitas bisnis seperti menemui klien atau sebagai tempat rapat (Solikatun, et al., 2015). Bagi penikmat kopi sejati, kualitas kopi menjadi alasan pemilihan tempat minum kopinya. Namun, bagi masyarakat umum terdapat begitu banyak alasan mengapa mereka memilih untuk duduk berlama-lama untuk sekedar minum kopi. Tradisi menikmati kopi sejak lama, telah ada di Indonesia. Minum kopi, pada mulanya hanya boleh dilakukan para orang dewasa hingga usia lanjut dan hanya kalangan pria. Namun seiring perubahan waktu para kaum wanita dan anak muda juga ikut mengkonsumsi minuman kopi seperti layaknya kaum pria dewasa sejak dahulu.

Kebiasaan minum kopi bagi masyarakat Manado berkembang seiring tumbuh dan berkembangnya kedai atau warung kopi di Kota Manado. Usaha rumah kopi di ibukota Provinsi Sulawesi Utara dapat ditemukan di berbagai tempat. Bahkan di pusat kota ada sebuah kawaswan yang terdapat puluhan warung kopi yang berada dalam satu lokasi yang dikenal dengan nama "Jalan Roda" atau lebih populer dengan "Jarod". Pemerintah Kota Manado kemudian menjadikan kawasan Jarod sebagai salah satu destinasi pariwisata kuliner di kota Manado. Kawasan wisata kuliner jalan roda atau yang di kenal sebagai Jarod merupakan tempat yang sangat strategis di kota Manado. Harga kopi yang terbilang murah membuat Warkop Jalan Roda (Jarod) menjadi tempat pilihan untuk menikmati kopi masyarakat dari berbagai kalangan (Ginano, et al., 2018).

Kondisinya pun bisa digolongkan ke dalam warung kopi yang sederhana tampilannya tidak dibuat keren seperti warung kopi modern pada umumnya. Mayoritas warung kopi di kawasan jalan roda (Jarod) dikololah dengan sederhana tetapi dibuat senyaman mungkin dan hanya besebagai tempat minuman kopi saja. Kondisi dan fasilitas yang disediakan juga sangat seadanya, jumlah tempat duduk yang tersedia di dalamnya sangat terbatas karena kondisi ruangannya memang sangat sederhana dari segi ukuran. Para pengunjung yang datang duduk semeja dengan orang lain yang belum dikenal sebelumnya. Kebanyakan menyediakan hanya sajian kopi dan cemilan khas manado. Dan proses penyajian kopi dengan hanya diseduh ataupun kopi siram.

Pengunjung Warkop jalan roda (Jarod) kota Manado sangat beragam. Secara umum para pengunjung dan waktu berkunjungnya dapat diklasifikasikan menjadi beberapa kategori. Mereka yang berkunjung di awal pagi merupakan para pekerja kantoran untuk sekedar mengawali pagi sebelum berangkat ke tempat kerja. Para karyawan swasta menggunakan warung kopi sebagai tempat konsolidasi saat sebelum 
melakukan aktivitas kerja. Saat siang hari, para pebisnis dan makelar akan akan memenuhi warkop. Dan saat sore hari kalangan pegawai kantoran yang selanjutnya menambah penggung kawasan jalan roda (Jarod) kota Manado.

Dari uraian diatas, penelitian ini akan berupaya menjawab bagaimana kawasan jalan roda (Jarod) sebagai ruang ekspresi waktu senggang (leisure) masyarakat kota Manado. Penelitin ini difokuskan pada warung kopi yang berada di kawasan kuliner jalan roda di kota Manado. Penentuan kawasan ini dengan melihat aspek lokasi kawasan jalan roda (Jarod) berada dilokasi pusat kota dan pertimbangan keramaian pengunjung warung kopi. Pertimbangan karena kawasan jalan roda (Jarod) merupakan titik kumpul semua kalangan masyarakat di kota Manado.

\section{TINJAUAN PUSTAKA}

Globalisasi dan gaya hidup menyebabkan perubahan prilaku pada masyarakat. Ini merupakan konsekuensi dari perluasan pengaruh kapitalisme pada setiap sendi kehidupan masyarakat. Kapitalisme dan industrilisasi berkaitan dengan melimpahnya produksi barang dan jasa. Masyarakat digoda oleh sensasi kemewahan ataupun budaya instan untuk terus malakukan aktivitas konsumsi yang tiada henti (Baudrillard, 2006). Budaya konsumtif menurut Jean Baudrillard merupakan merupakan aktivitas konsumsi barang dan jasa tidak lagi sekedar untuk memenuhi kebutuhan secara fungsional, tetapi juga sebagai tempat berburu citra simbolik yang melekat pada produk yang dikonsumsi itu. Konsumsi saat ini dapat mengespreesikan posisi sosial seseorang dan identitas kultural seseorang pada suatu masyarakat karena sesuatu yang dikonsumsi tidak berupa objek semata, namun juga terdapat makna - makna sosial yang berada dibaliknya barang yang dikonsumsi tersebut (Piliang, 2011).

Dalam budaya konsumen terdapat tiga perspektif yang beroperasi. Pertama bahwa budaya konsumsi dipremiskan dengan ekspansi produksi komoditas kapitalis yang memunculkan akumulasi yang besar-besaran budaya dalam bentuk barang-barang konsumen dan tempat-tempat belanja dan konsumsi. Hal inin mengakibatkan tumbuhnya kepentingan aktivitas bersenang-senang dan konsumsi dalam masyarakat kontenporer, yang walaupun disepakati oleh beberapa ahli menyebabkan adanya sifat efalitarianisme dan kebebasan individu yang lebih besar, oleh alhi-ahli lain dipandang meningkatkan kapasitas untuk melakukan manipulasi ideologis dan pengekangan masyarakat yang bersifat seduktif dari beberapa alternative hubungan sosial yang lebih baik.

Kedua bahwa kepuasan berasal dari benda-benda yang berhubungan dengan akses benda-benda itu yang terstruktur secara sosial dalam suatu peristiwa yang telah ditentukan yang didalamnya kepuasan dan status tergantung pada penunjukan dan pemeliharaan perbedaaan dalam kondisi inflasi. Titik perhatiannya disini adalah pada 
Community: volume 6, nomor 1, April 2020

p-ISSN: 2477-5746 e-ISSN: 2502-0544

acara-cara yang berbeda dimana orang menggunakan benda-benda dalam rangka menciptakan ikatan-ikatan atau perbedaan masyarakat. Ketiga adaanya masalah kesenangan emosional untuk komsumsi, mimpi-mimpi dan keinginan ditampakkan dalam bentuk tamsil budaya konsumen dan tempat-tempat konsumsi tertentu yang secara beragam memunculkan kenikmatan jasmani langsung serta kesenangan estetis (Featherstone, 2008)

Dalam tradisi minum kopi saat ini, telah mengalami pergeseran. Jika minum kopi yang menurut medis kandungannya bias memberi efek menghilangkan rasa kantuk, mejaga kebugaran tubuh, dan membuat pikiran selalu fokus. Kenyataannya telah bergeser sebagai suatu gaya hidup, menjadi identik budaya konsumtif. Masyarakat menikmati kopi sambal istirahat, berbincang-bincang bahkan sambil mengerjakan pekerjaannya di warung kopi. Kebiasaan ini merupakan aktifitas yang mengisi waktu luang (Leisure) dalam masyarakat saat ini. Masyarakat menghabiskan waktu dan uang untuk sekedar nongkrong lama di warung kopi. Aktivitas konsumtif dan pemanfaatan waktu luang (Leisure) menjadi kebutuhan tersendiri.

Tidak hanya sekedar beristirahat ataupun melaksanakan rutinitas, tetapi juga mengekspresikan status sosial dan gaya hidup. Masyarakat memanfaatkan waktu luang (leisure) dengan kegiatan konsumtif. Hal ini menurut Thorstein Veblen sebagai "kelas pemboros" menurutnya perbedaan kepemilikan waktu luang seseorang sangat bergantung pada kekayaan materi yang dimiliki, seseorang yang memiliki kekayaan materil lebih berbanding lurus dengan kepemilikan waktu luang, karena menurutnya orang tersebut tidak akan sibuk bekerja untuk memenuhi kebutuhan sehari-harinya. Dengan materi yang lebih seseorang dapat menggunakan sesuka hati tanpa memikirkan waktu untuk bekerja.Sementara, bagi orang yang tidak memiliki kekayaan, tentu saja akan kesulitan dalam memiliki waktu luang sebab sebagian besar waktunya digunakan sebagai kesibukan untuk bekerja, untuk memenuhi kebutuhan sehari-harinya dan tidak memiliki kesempatan untuk menggunakan waktu luangnya (Veblen, 2007).

Aktivitas konsumsi dan waktu luang telah menjadi fenomena kontenporer saat ini. Pemanfaatan waktu luang untuk aktivitas konsumsi tidak lagi diukur dari sebesar apa kekayaan yang dimiliki seseorang, saat ini waktu luang hanya diartikan sebagai waktu lebih yang memiliki sifat membebaskan. Pada dasarnya waktu luang dimiliki oleh setiap orang, Perbadaannya hanya terdapat pada bagaimana seseorang tersebut memanfaatkan waktu luangnya sebaik mungkin. Terdapat tiga tipe orang yang berhubungan dengan waktu luang (Pamungkas, 2016). Pertama adalah seseorang yang memiliki waktu luang dan waktu luang tersebut dapat dimanfaatkan sebaik-baiknya dengan melakukan kegiatan atau aktivitas yang sesuai kebutuhan. Kedua adalah seseorang yang memiliki waktu luang, namun waktu luang tersebut hanya digunakan untuk kegiatan-kegiatan yang kurang bermanfaat, sementara yang ketiga adalah 
seseorang yang memiliki waktu luang, namun waktu luang tersebut tidak dapat dimanfaatkan secara maksimal karena terlalu banyak kesibukkan di bidang lain.

Jadi, waktu luang (Leisure) diperoleh tidak lagi berdasarkan kekayaan melainkan bagaimana seseorang tersebut dapat menggunakan waktu lebih tersebut secara maksimal. Maksimal dalam artian waktu luang tersebut dapat digunakan dengan berbagai macam kegiatan. Kegiatan dan waktu luang merupakan sesuatu yang tidak dipisahkan karena kegiatan membutuhkan waktu luang sementara itu waktu luang memunculkan kesempatan untuk berkegiatan.

Waktu luang (Leisure) berhubungan dengan sikap seseorang dalam menentukan sebuah kegiatannya. Thorstein Veblen menyatakan "The Theory of the Leisure Class" bahwa pada hakikatnya setiap orang memiliki perbedaan kelas, jika menurut Karl Marx perbedaan kelas terletak pada kepemilikan modal yang dimiliki seseorang tetapi menurut Veblen perbedaan kelas terletak pada pemanfaatan waktu luang yang digunakan seseorang. Dari situ Veblen berpendapat terdapat kelas sosial baru yang bernama "Leisure Class" yang jika diartikan, adalah sebuah individu yang memiliki waktu berlebih untuk dapat digunakan atau dimanfaatkan untuk sesuatu. (Veblen, 2007).

Secara umum aktivitas The Leisure Class merupakan cara menikmati hidup dengan aktivitas mengonsumsi waktu luang. Waktunya dihabiskan hanya demi kenikmatan untuk diri atau kelompok. Veblen menyebut sebagai "kelas pemboros" yang menurutnya aktivitas ini tidak memiliki tujuan apa-apa, melainkan untuk melanggengkan kesenjangan dan hierarki sosial yang ada.

\section{METODE PENELITIAN}

Penelitian ini merupakan jenis penelitian kualitatif yaitu penelitian yang memberikan penjelasan tentang fakta secara mendalam tentang fenomena keberadaan kawasan kuliner jalan roda di kota Manado sebagai sarana atau ruang ekspresi waktu senggang bagi masyarakat kota Manado. Penelitian kualitatif adalah penelitian yang mendeskripsikan dan menganalisis makna yang terkandung dibaliknya fenomena sebagai makna yang tersembunyi, atau dengan sengaja disembunyikan sehingga menghasilkan data deskriptif dalam bentuk kata-kata, baik tertulis maupun lisan (Sugioyono, 2017)

Penelitian ini dilakukan di kota Manado provinsi Sulawesi Utara disebabkan karena kota Manado merupakan kota yang sedang berkembang dikawasan Sulawesi Bagian utara. Industri perdagangan bertumbuh dengan pesat, termasuk semakin banyaknya dibangun warung kopi mulai dari warung kopi yang bergaya tradsional hingga yang bergaya modern.

Fokus penelitian ini adalah menjelaskan fenomena warung kopi yang berada di kawasan kuliner jalan roda di kota Manado. Kawasan ini ditentukan sebagai tempat 
Community: volume 6, nomor 1, April 2020

p-ISSN: 2477-5746 e-ISSN: 2502-0544

mengumpulkan data dengan melihat beberapa aspek pertimbanggan yaitu merupakan perwakilan warung kopi yang berada di sekita pusat perkotaan Manado dan juga merupakan wilayah dipinggiran kota, selain itu factor intensitas keramaian kunjungan ke warung kopi juga sangat diperhatikan. Pertimbangan lainnya adalah kawasan jalan roda (Jarod) sebab merupakan salah satu titik kumpul semua kalangan masyarakat di kota Manado.

Teknik pengumpulan data dalam penelitian ini dilakukan dengan metode yaitu pengamatan (observasi) merupakan metode pengumpulan data yang digunakan untuk menghimpun data penelitian melalui pengamatan dengan panca indra, wawancara (interview) merupakan percakapan dengan maksud tertentu yaitu dengan wawancara bebas dan mendalam, dan dokumentasi merupakan pengumppulan data sekunder melalui pengambilan gambar di lokasi berupa dokumen atau foto. Proses analisis dalam penelitian kualitatif, secara khusus kegiatannya dilakukan secara induktif, interaksi dari setiap unit datanya, bersamaan dengan proses pelaksanaan pengumpulan data, dan dengan proses siklus (Miles \& Huberman, 2014). Empat komponen utama analisis tersebut adalah pengumpulan data, reduksi data, sajian data, penarikan kesimpulan. Menguji keabsahan data penelitian menggunakan metode Trianggulasi, yaitu pemeriksaan keabsahan data yang memanfaatkan sesuatu yang lain di luar data untuk keperluan pengecekan atau sebagai pembanding terhadap data tersebut, dan teknik trianggulasi yang paling banyak digunakan adalah dengan pemeriksaan melalui sumber yang lainnya.

\section{TEMUAN DAN PEMBAHASAN}

Kota Manado, merupakan ibu kota dari provinsi Sulawesi Utara. Secara administrasi, kota Manado sejak 2012 mengalami pemekaran menjadi 11 kecamatan serta 87 kelurahan, dimana 10 kecamatan terletak pada daratan utama pulau Sulawesi dan 1 kecamatan berbentuk kepulauan. Kecamatan wenang merupakan kecamatan dengan jumlah kelurahan paling banyak yaitu memiliki 12 keluramatan yang jumlah kelurahan terkecil adalah kepulauan Bunaken yang hanya memiliki 4 kelurahan. Kota Manado secara administratif berada di wilayah teluk Manado serta dikelilingi oleh pegunungan. Tahun 2018 tercatat 62.225 orang memiliki KTP (Manado, 2020).

Bagi masyarakat Manado, kebiasaan minum kopi telah ada sejak lama. Seiring dengan perkembangan waktu, bermula dari sebagai daerah di kawasan jalan roda (Jarod) dari masa kolonial belanda, dimana pada masa tersebut, terdapat sebuah jalan yang merupalkan area peristirahatan para pedagang yang datang dari Minahasa, dengan menggunakan alat tranportasi sejenis pedati yang mereka sebut "roda". Dan di area jalan tersebut berderet rumah - rumah kopi yang berjualan hingga pukul 10 malam. Ditempat ini lah para pedagang dari Minahasa beristirahat (Ginano, et al., 2018). 
Hingga saaat ini kawasan itu semakin berkembang dan menjadi pusat pertemuan seluruh kalangan masyarakat di kota Manado. Seiring perkembangan masa kebiasan minum kopi masyarakat kota Manado tidak lagi sekedar menikmati kopi semata, seperti umumnya tetapi telah bergeser sebagai tempat berbincang dengan bebas, berbagi gagasan, membincang segala hal terkait permasalahan dan persoalan yang ada disekitarnya. Perihal konstalasi politik juga menjadi bahan pembahasan di warung kopi jalan roda (Jarod), selain itu warung kopi jalan roda (Jarod) menjadi tempat sarana aktivitas bisnis dan juga tempat para pelajar maupun mahasiswa nongkrong ataupun berdiskusi.

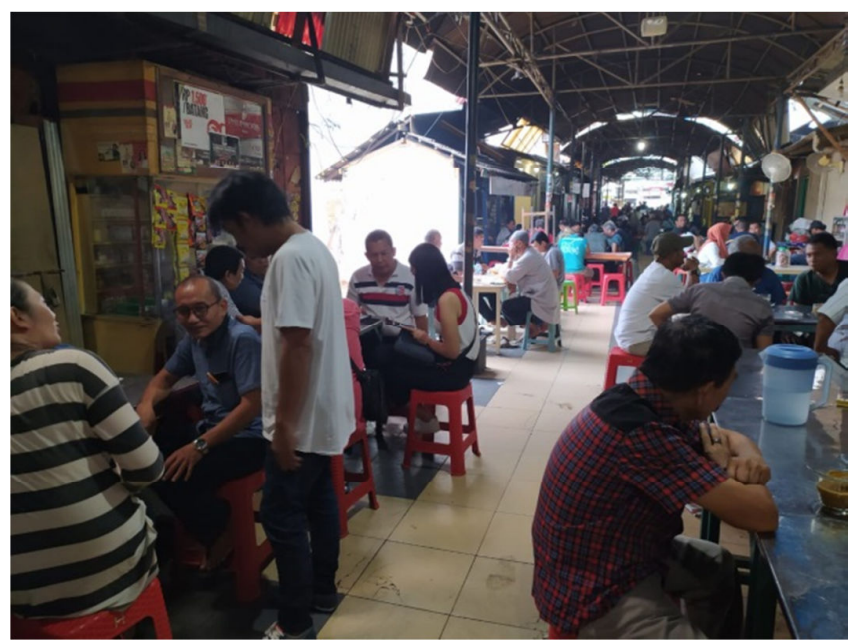

Gambar 4.1: Suasana Di Kawasan Jalan Roda (Jarod) Kota Manado

\section{a. Warkop Jarod Sebagai Ruang Politis}

Perilaku mengomsumsi kopi saat ini merupakan bagian dari gaya hidup bagi para pengunjung kawasan jalan roda (Jarod). Para aktor politik dan warung kopi merupakan fenomena yang sering ditemukan dimana-mana. Komunitas ini menjadikan warung kopi arena berdiskusi menyampaikan gagasan, lobi - lobi, atau menemui konstituennya serta mensosialisasikan agenda politik mereka.ini berarti bahwa bagi mereka, warung kopi merupakan salah satu tempat untuk membangun citra diri. Di warung kopi mereka bebas menyampaikan gagasannya, tanpa ada larangan dari pihak manapun. Dengan mudah kita akan menemukan foto-foto atau baliho politisi terpajang disudut-sudut warkop jalan roda (Jarod).

Pengunjung warkop jalan roda (Jarod) datang dari berbagai unsur masyarakat. Hal ini yang membuat kalangan politisi menjadi betah untuk nongkrong berlama-lama di warkop jalan roda (Jarod). Ini merupakan sarana yang dapat menjadi akses dan pintu 
Community: volume 6, nomor 1, April 2020

p-ISSN: 2477-5746 e-ISSN: 2502-0544

masuk bagi mereka yang melakukan sosialisasi, menyampaikan ide-ide dan gagasan, serta ajang pencitraan diri. Tidak hanya para politisi lokal, bahkan warkop jalan roda (Jarod) pernah di kunjungi Presiden Jokowi ketika moment PILPRES 2019 lalu.

\section{b. Wakop Jarod Sebagai Pusat Informasi}

Perluasan fungsi dan pergeseran makna warkop jalan roda (Jarod) yang menarik untuk didiskusikan adalah fungsi warung kopi menjadi arena untuk menghimpun informasii. Para awak media menjadikan warkop jalan roda (Jarod) sebagai tempat mencari informasi pemberitaan terkait isu-isu yang hangat dan jadi pembicaraan publik.

Warkop jalan roda (Jarod) menjadi tempat favorit bagi para wartawan, baik sendiri maupun berkelompok. Saat berkelompok mereka dapat bertukar informasi yang nantinya dikembangkan menjadi bahan pemberitaan. Sementara itu para jurnalis juga menjadikan para politisi yang berada di warkop jalan roda (Jarod) sebagai sumber pemberitaan. Para awak media akan mendapatkan informasi yang melimpah di warkop JAROD karena di sana merupakan tempat pertemuan segala jenis kalangan. Dan terkadang informasi yang sifatnya rahasia, didiskusikan di warkop jalan roda (Jarod). Diskusi orang-orang mengalir lancar, sehingga informasi yang rahasia tanpa sengaja disampaikan, pada saat itulah para wartawan bias mendengarkan informasi, kemudian menjadikannya bahan untuk pemberitaan.

\section{c. Warkop Jarod Ruang Sarana Bisnis}

Seiring perkembangan Kota Manado, mulai dari pertumbuhan jumlah dan peningkatan fasilitas maupun pelayanan publik, orientasi masyarakat berkunjung kewarung kopi semakin beragam pula. Kebiasaan menghabiskan waktu luang (leisure) di kawasan jalan roda (Jarod) dilakukan para pelaku bisnis, mereka tau betul memanfaatkan situasi warkop jalan roda (Jarod) yang padat pengunjung setiap harinya. Para SPG rokok ataupun produk lainnya. Menjajakan jualan mereka kepada para pengunjung warkop JAROD. Para kolektor pembiayaan menggunakan warkop JAROD sebagai tempat rapat dengan rekanan mereka. Membicarakan kendala-kendala yang mereka temui dan mencari solusi bersama-sama. Selain itu para "calo" tanah menjadikan kawasan ini sebagai "tempat kerja" mereka, mereka menjumpai klien di kawasan ini untuk melakukan transaksi, atau sekedar berjumpa dengan teman seprofesinya.

\section{d. Warkop Jarod Arena Diskusi bagi Mahasiswa/Pelajar.}

Kalangan pelajar dan mahasiswa merupakan salah satu pengunjung aktif warung kopi saat ini Kini kalangan mahasiswa menjadi bagian dari pengunjung di kawasan jalan roda (Jarod) hingga waktu yang lama. Mereka mengunjungi warung kopi kepada penggunaan aksess internet gratis yang biasanya tersedia di setiap warung kopi. Hal ini 
tentu saja akan membantu meleka dalam mengerjakan tugas kampus mereka. Mereka datang berkelompok, baik itu dengan teman kuliah ataupun dengan komunitas di organisasi kampus. Saat berkumpul mereka akan berdiskusi tentang kesibukan di kampus ataupun kegiatan kemahasiswaan yang mereka laksanakan di sela kesibukan kuliah. Selain itu kalangan mahasiswa menghabiskan waktu yang lama untuk sekedar nongkrong dan berbincang-bincang telah menjadi trend tersendiri bagi mereka.

\section{e. Warkop Jarod Sebagai Ruang Hiburan}

Kebiasaan minum kopi di kawasan jalan roda (Jarod) telah mnjadi keseharian masyarakat di Kota Manado. Banyak orang sekedar menikmati secangkir kopi dengan harga yang terbilang murah. Fasilitas di kawasan jalan roda (Jarod) tebilang sederhana hanya kursi kayu dan meja panjang. Para pengunjung bebas sesuka hati untuk sekedar diskusi atau tertawa lepas. Fungsi kawasan jalan roda (Jarod) sebagai tempat hiburan menajdi salah satu daya tarik orang-orang mengunjungi kawasan ini. Ada yang sekedar datang untuk bermain catur, domino atau permainan mahyong sambil menikmati kuliner khas manado. Para pengunjung kawasan jalan roda (Jarod) berasal dari multi etnis, semua berbaur menjadi satu dalam kawasan ini. Di mana Kota manado yang masyarakatnya merupakan multi agama. Di kawasan ini kita bias menyaksikan berbaurnya keberagaman tanpa melihat perbedaan status. Di deretan mejanya kita akan melihat anak muda yang duduk dengan kalangan orang-orang tua, umat Kristen yang duduk semeja dengan umat Islam. Mereka asyik, larut dalam perbincangan atau sekedar bermain domino bersama. Selain itu bentuk hiburan lain yang diperoleh pengunjung lain adalah perbermainan game online, permainan domino dan kartu. Dan terdapat bentuk hiburan lain yang sajikan para pengelolah di kawasan ini adalah acara karaokean pada waktu-waktu tertentu.

Kehadiran warung kopi di Kawasan Jalan Roda (Jarod) Kota Manado saat ini merupakan pilihan bagi masyarakat untuk mengekprisikan waktu luang (leisure). Perilaku mengomsumsi kopi setiap pengunjung kawasan ini tentu akan berbeda-beda sesuai dengan latarbelakang pekerjaan ataupun status sosialnya. Ini menyebabkan pemaknaan terhadap aktivitas nongkrong di kawasan jalan roda (Jarod).

\section{f. Pemaknaan Warung Kopi Sebagai Ekspresi Waktu Luang (Leisure) Di Kawasan Wisata Kuliner Jalan Roda Kota Manado.}

Makna berkunjung ataupun nongkrong di warung kopi bagi masyakat di Kawasan Wisata Kuliner Jalan Roda (Jarod) Kota Manado telah mengalami pergeseran dari tradisi minum kopi yang hanya sekedar untuk menikmati cita rasa kopi apa adanya, saat ini telah bergeser menjadi suatu budaya popular. Seseorang menemukan identitas dirinya sangat bergantung dari akivitas konsumsi yang dilakukan. Kualitas barang atau jasa yang dikonsumsi berbanding lurus dengan status sosial yang diperoleh. Kenyataan 
Community: volume 6, nomor 1, April 2020

p-ISSN: 2477-5746 e-ISSN: 2502-0544

ini telah menjadi sebagai suatu gaya hidup, yang identik budaya konsumtif. Masyarakat menikmati kopi sambil istirahat, berbincang-bincang bahkan sambil mengerjakan pekerjaannya di warung kopi.

Kebiasaan ini telah menjadi aktifitas mengisi waktu luang (Leisure) pada masyarakat di Kawasan Wisata Kuliner Jalan Roda (Jarod) Kota Manado. Masyarakat menghabiskan waktu dan uang untuk sekedar nongkrong lama di warung kopi. Aktivitas konsumtif dan pemanfaatan waktu luang (Leisure) menjadi kebutuhan tersendiri. Para pengunjung Kawasan Jalan Roda (Jarod) tidak hanya sekedar beristirahat ataupun melaksanakan rutinitas, tetapi juga mengekspresikan status sosial dan gaya hidup. Mereka memanfaatkan waktu luang (leisure) lebih kepada hal - hal yang identik dengan kegiatan konsumtif. Hal ini menurut Thorstein Veblen sebagai "kelas pemboros" menurutnya perbedaan kepemilikan waktu luang seseorang sangat bergantung pada kekayaan materi yang dimiliki, seseorang yang memiliki kekayaan materil lebih berbanding lurus dengan kepemilikan waktu luang, karena menurutnya orang tersebut tidak akan sibuk bekerja untuk memenuhi kebutuhan sehari-harinya. Dengan materi yang lebih seseorang dapat menggunakan sesuka hati tanpa memikirkan waktu untuk bekerja.Sementara, bagi orang yang tidak memiliki kekayaan, tentu saja akan kesulitan dalam memiliki waktu luang sebab sebagian besar waktunya digunakan sebagai kesibukan untuk bekerja, untuk memenuhi kebutuhan sehari-harinya dan tidak memiliki kesempatan untuk menggunakan waktu luangnya (Veblen, 2007).

Aktivitas konsumsi dan waktu luang telah menjadi fenomena kontenporer saat ini. Pemanfaatan waktu luang untuk aktivitas konsumsi bagi masyarakat di Kawasan Wisata Kuliner Jalan Roda (Jarod) Kota Manado tidak lagi diukur dari sebesar apa kekayaan yang dimiliki seseorang, tapi saat ini diartikan sebagai waktu lebih yang memiliki sifat membebaskan. Pada dasarnya waktu luang dimiliki oleh setiap orang terdapat pada bagaimana seseorang tersebut memanfaatkan waktu luangnya sebaik mungkin.

Terdapat tiga tipe orang yang berhubungan dengan waktu luang (Pamungkas, 2016). Pertama adalah seseorang yang memiliki waktu luang dan waktu luang tersebut dapat dimanfaatkan sebaik-baiknya dengan melakukan kegiatan atau aktivitas yang sesuai kebutuhan. Kedua adalah seseorang yang memiliki waktu luang, namun waktu luang tersebut hanya digunakan untuk kegiatan-kegiatan yang kurang bermanfaat, sementara yang ketiga adalah seseorang yang memiliki waktu luang, namun waktu luang tersebut tidak dapat dimanfaatkan secara maksimal karena terlalu banyak kesibukkan di bidang lain.

Jadi, waktu luang (Leisure) diperoleh tidak lagi berdasarkan kekayaan melainkan bagaimana seseorang tersebut dapat menggunakan waktu lebih tersebut secara maksimal. Maksimal dalam artian waktu luang tersebut dapat digunakan dengan berbagai macam kegiatan. Kegiatan dan waktu luang merupakan sesuatu yang tidak 
dipisahkan karena kegiatan membutuhkan waktu luang sementara itu waktu luang memunculkan kesempatan untuk berkegiatan. Waktu luang (Leisure) berhubungan dengan sikap seseorang dalam menentukan sebuah kegiatannya. Thorstein Veblen menyatakan "The Theory of the Leisure Class" bahwa pada hakikatnya setiap orang memiliki perbedaan kelas, jika menurut Karl Marx perbedaan kelas terletak pada kepemilikan modal yang dimiliki seseorang tetapi menurut Veblen perbedaan kelas terletak pada pemanfaatan waktu luang yang digunakan seseorang. Dari situ Veblen berpendapat terdapat kelas sosial baru yang bernama "Leisure Class" yang jika diartikan, adalah sebuah individu yang memiliki waktu berlebih untuk dapat digunakan atau dimanfaatkan untuk sesuatu. (Veblen, 2007).

\section{PENUTUP}

Tradisi minum kopi di kawasan jalan roda (Jarod) kota Manado telah mengalami pergeseran. Jika minum kopi yang menurut medis kandungannya bisa memberi efek menghilangkan rasa kantuk, menjaga kebugaran tubuh, dan membuat pikiran selalu fokus. Kenyataannya telah bergeser sebagai suatu gaya hidup, menjadi identik budaya konsumtif. Masyarakat menikmati kopi sambal istirahat, berbincang-bincang bahkan sambil mengerjakan pekerjaannya di warung kopi. Kebiasaan ini merupakan aktifitas yang mengisi waktu luang (Leisure) dalam masyarakat saat ini. Masyarakat menghabiskan waktu dan uang untuk sekedar nongkrong lama di warung kopi. Secara umum aktivitas The Leisure Class merupakan cara menikmati hidup dengan aktivitas mengonsumsi waktu luang. Waktunya digunakan hanya demi kenikmatan untuk diri atau kelompok.

Pengunjung Warkop jalan roda (Jarod) kota Manado sangat beragam. Dapat dikelompokkan menjadi beberapa kategori. Pertama para aktor politik yang menjadikan warung kopi arena berdiskusi menyampaikan gagasan, lobi - lobi, atau menemui konstituennya serta mensosialisasikan agenda politik mereka.ini berarti bahwa bagi mereka, warung kopi merupakan salah satu tempat untuk membangun citra diri. Kedua para jurnalis yang juga menjadikan para politisi yang berada di warkop jalan roda (Jarod) sebagai sumber pemberitaan. Para awak media akan mendapatkan informasi yang melimpah di kawasan ini karena di sana merupakan tempat pertemuan segala jenis kalangan. Dan terkadang informasi yang sifatnya rahasia, didiskusikan di warkop jalan roda (Jarod). Diskusi orang-orang mengalir lancar, sehingga informasi yang rahasia tanpa sengaja disampaikan, pada saat itulah para wartawan bias mendengarkan informasi, kemudian menjadikannya bahan untuk pemberitaan.

Ketiga para pelaku bisnis, mereka memanfaatkan situasi kawasan jalan roda (Jarod) yang padat pengunjung setiap harinya. Para SPG rokok ataupun produk lainnya. Menjajakan jualan mereka kepada para pengunjung kawasan ini. Dan para kolektor 
Community: volume 6, nomor 1, April 2020

p-ISSN: 2477-5746 e-ISSN: 2502-0544

pembiayaan menggunakan kawasan jalan roda (Jarod) sebagai tempat rapat dengan rekanan mereka. Keempat kalangan pelajar dan mahasiswa merupakan salah satu pengunjung aktif warung kopi saat ini yang sebelumnya menjadi warung kopi menjadi sarana pelepas rasa kantuk, kini mahasiswa telah mengisi ruang di kawasan jalan roda (Jarod) hingga waktu yang lama. Mereka datang berkelompok, baik itu dengan teman kuliah ataupun dengan komunitas di organisasi kampus. Saat berkumpul mereka akan berdiskusi tentang kesibukan di kampus ataupun kegiatan kemahasiswaan yang mereka laksanakan di sela kesibukan kuliah. Kelima para pengunjung kawasan jalan roda bebas sesuka hati untuk sekedar diskusi atau tertawa lepas. Fungsi kawasan ini sebagai tempat hiburan menajdi salah satu daya tarik orang-orang mengunjungi kawasan ini. Ada yang sekedar datang untuk bermain catur, domino atau permainan mahyong sambil menikmati kuliner khas manado.

\section{DAFTAR PUSTAKA}

Baudrillard, J., 2006. Masyarakat Konsumsi. Yogyakarta: Kreasi Wacana.

Featherstone, M., 2008. Postmodern dan Budaya Konsumen. Yogyakarta: Pustaka Pelajar.

Ginano, A. B. R., Kusen, A. W. S. \& Marawa, J. E. T., 2018. Kehidupan Jalan Roda Kota Manado. HOLISTIK, Volume Tahun XI, p. No 21.

Manado, B. K., 2020. Kota Manado Dalam Angka: Manado Municipality in Figures.. Manado: BPS Kota Manado.

Miles, M. B. \& Huberman, M. B., 2014. Analisis Data Kualitatif : Buku Sumber Tentang Metode - Metode Baru. Jakarta: UI-Press.

Pamungkas, N. R., 2016. Solilokui Waktu Senggang (Sebuah Praktik "Anggota" Budaya Populer dan Diskursus Konsumtivisme). Departemen Sosiologi, Fakultas Ilmu Sosial dan Politik Universitas Airlangga Surabaya.

Piliang, Y. A., 2011. Dunia Yang Dilipat, Tamasya melampaui batas-batas kebudayaan. s.1.:Matahari.

Solikatun, Kartono, D. T. \& Demartoto, A., 2015. Perilaku Konsumsi Kopi Sebagai Budaya Masyarakat konsumsi: Studi Fenomenologi Pada Peminum Kopi Di Kedai Kopi Kota Semarang. Jurnal Analisa Sosiologi, pp. 60 - 74.

Sugioyono, 2017. Metode Penelitian Kuantitatif, Kualitatif dan R\&D. Bandung: Alfabeta.

Sutopo, H. B., 2006. Metode Penelitian Kualitatif. Surakarta: UNS. 
Community: volume 6, nomor 1, April 2020

p-ISSN: 2477-5746 e-ISSN: 2502-0544

Veblen, T., 2007. The Theory of The Leisure Class. New York: Oxford University Press. 